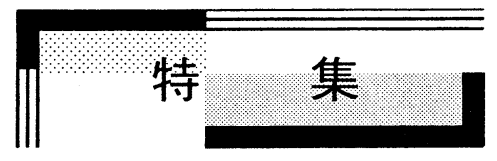

\title{
液膜流の測定法 *
}

\author{
Measurement Techniques for Film Flow
}

\author{
芹 澤 昭 示** \\ SERIZAWA Akimi
}

\begin{abstract}
This report is a state of the art review of recent developments in measurement techniques for liquid film flows in gas-liquid systems. Our concerns are rapidly moving towards clarifying detailed structures of film flows in spatial and time domains dominating the mechanisms. This report focuses, along with typical conventional methods, recent advancements in film flow measurements mainly brought about by the developments in computer technologies, electronics and optics.
\end{abstract}

Keywords : film thickness, dye tracer, conductance probes, optical methods, acoustic transmission

\section{1. はじめに}

気液二相流の液膜流は多くの工学分野で見られ、 環状流、環状噴霧流、層状流などの気液二相流流 動様式の基本的な流れの構成を特徵づけている。 古くは化学工学の濡壁塔における流下液膜やボイ ラ一等の問題として、また、近年は、原子炉想定 事故あるいは過酷事故時の燃料棒周りの液膜流挙 動と熱的限界との係わり、あるいは高性能燃料集 合体開発に係わる熱水力現象の素過程として、ま た、核融合炉におけるプラズマからの熱流や粒子 流から炉壁を守るための液体金属や溶融塩液膜流 の応用、エネルギー・環境問題から派生した液膜 流による炭酸ガスの吸収等々、私たちの生活と液 膜流との関係は浅くない。

気液二相流の計測技術の向上については多方面 で多くの努力がなされてきており、そのための国 際会議、専門家会議などが開催される一方、解説書、 解説記事、国際会議講演論文集、ジャーナルの特 集号などが国内外で出版されている（たとえば、 [1]-[8])。こうした研究の歷史は 1940 年代に遡る が、1960 年代の原子力技術開発に伴って急速に発 展した経緯がある。特に, 数值解析手法の高度化 やコンピュータの高性能化によって、従来の実験
技術では測定が困難であった二相流特性のかなり の部分を数值計算によって予測することが可能と なった。それとともに、二相流現象の多次元（局 所）特性や時間依存特性の実験データが求められ るようになった。すなわち，優れた時間・空間分 解能を有し, かつ、非接触による詳細で精緻な測 定を保証する計測手法の開発が望まれている。特 に、通常の機器で見られる液膜流の多くは薄い液 膜からなるものが多く, 接触型測定法や流れを抽 出するような古典的測定法は、流れに付加的な擾 乱を与えたり, 流れの組織構造を変化させてしま う恐れがあるため、可能な限り避けるほうが賢明 である。開発された多くの手法は時間・空間分解 能、適用性と汎用性、コストなどの点で一長一短 があり、使用環境に合わせた最適な手法の選択が 必要である。本稿では接触型をも含めて, 液膜厚 さ、表面波形状、液膜流量、液膜内速度、壁面せ ん断応力等の基本的物理量の代表的な測定方法を 概説し，それらによる測定例を参考として示す。

\section{2. 写真撮影法}

これは液膜の表面形状や液膜内の流れの様子を 観察あるいは測定する最も直接的な方法であるが、

* 2000.2.26 受付

** 京都大学大学院工学研究科原子核工学専攻 干606-8501 京都府京都市左京区吉田本町 TEL(075)753-5829 FAX(075)753-5829 E-mail : serizawa@nucleng.kyoto-u.ac.jp 
光源やカメラなどの配置に工夫がいる。

\section{1 直接撮影法}

Fig.1 はストロボ光源を流れに対して傾斜させ て撮影する場合で、液膜表面波に陰影ができ、表 面の波の様子を知ることができる（Fig.2）。極め て簡単な方法である。Fig.3 は矩形流路内を流れる 垂直水液膜流中に酸化チタンの微粒子を混入し、 チタン粒子による光の散乱を利用して撮影した液 膜厚さ分布の様子を示す写真である（萩原 [9]）。

\section{2 光減衰法}

これは流体中に顔料 (大場 [10]) やインク (Clark ら [11]) などを混入し, 液膜流背後からの透過光強

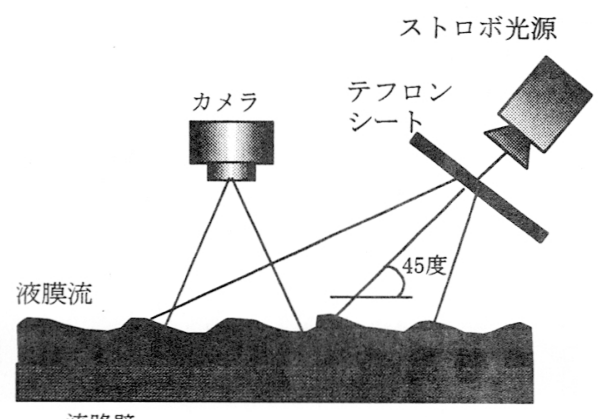

流路壁

Fig.1 Conventional Camera Technique (CCT)

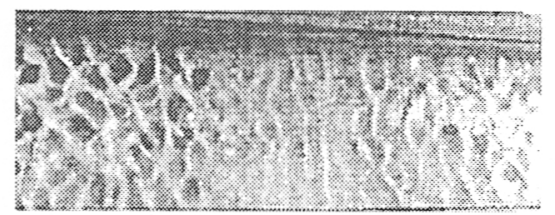

Fig.2 Waves on Film Flow Captured by CCT

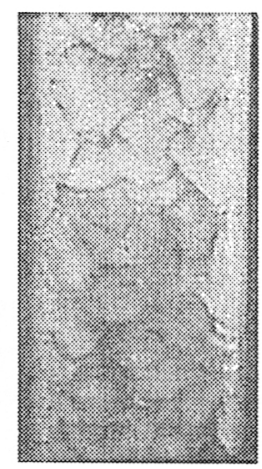

Fig.3 Film Flow Visualized with $\mathrm{TiO}_{2}$ Powder [9]
度が液膜厚さに依存して減衰するのを利用して、 濃淡（またはグレイ度）画面から液膜厚さを求め るものである（Fig.4）。透過光強度と液膜厚さの 関係は予め較正用セルを用いて求めておく。Fig.5 は Clark らによる希薄インク溶液で得られた写真 である。

一方, 試験部頂部から流路断面の液膜挙動や液 滴の飛散軌跡などを写真撮影する方法が Hewitt ら[12]により開発されている(Fig.6)。これはカメ ラ面に液滴や液膜が付着しないようにエアーパー ジを行うもので、同様な手法は水平流路で筆者ら も試みている $[13,14]$ 。Fig.7 は垂直円管内を上昇 する環状噴霧流の液膜の様子を試験部頂部から撮 影したものである [12]。観察すべき流路断面にイ リュミネーションを与え、カメラの焦点面をそこ に合わせて撮影する方法もある。色の異なる 2 種 類のイリュムネーションを流路方向の 2 断面に対

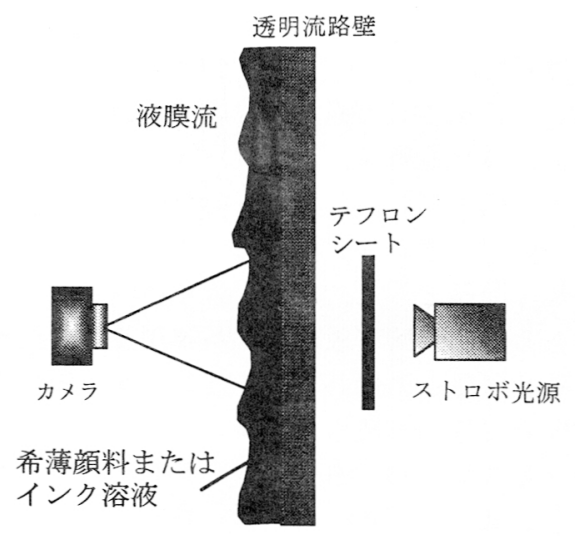

Fig.4 Light Attenuation

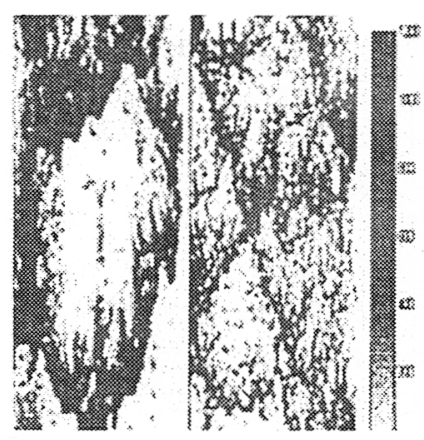

Fig.5 A Photograph Taken by Light Attenuation Using Black Ink [11] (Maximum Grey Level: $1200 \mu \mathrm{m})$ 


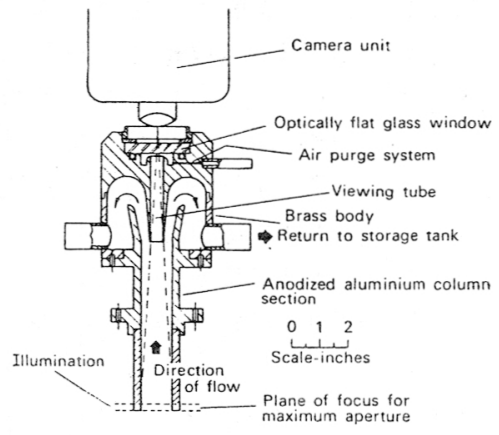

Fig.6 Air-Purge System [12]

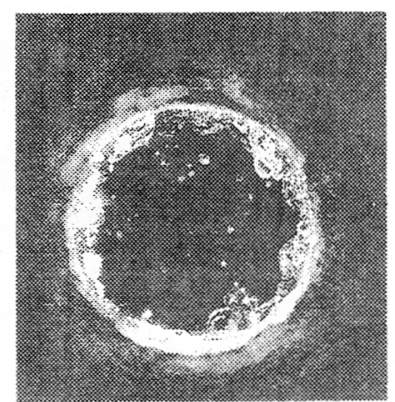

Fig.7 Cross Sectional View of Liquid Film in Vertically Upward Flow in a Pipe [12]

して付与すれば、その 2 断面間を通過する波や 液滴の移動速度も求められる。

\section{3 光発色性染料・蛍光染料法}

写真あるいは高速ビデオ撮影によって液膜表面 波挙動や液膜内速度場を観察する他の方法に光発 色性染料 (photochromic dye) や蛍光染料 (fluore -scence dye) 法がある[1]。これは紫外光 (UV) やレーザーなど特定波長領域の光による化学反応 で発色したり、あるいは励起し蛍光を発する物質 を作動流体中に微量溶解し、測定断面にシート状 または点状のレーザー光（またはUV 光）を連続的 またはパルス状に照射し、発色または発光を観察 するものである。Fig.8 に photochromic dye tracing を用いた Hewitt らによる光学測定系を示す[15]。 用いたパルスレーザーは出力 $0.3 \mathrm{~mJ}$ の窒素 UV レ ーザーで、発色性染料トレーサは 1'3'3' trimethyl indolinobenzo-pyran photochromic dye である(作動 流体はトリクロロエチレン)。川路も作動流体にケ ロシンを、発色染料に trimethylindoline-6-nitrobenzopiropyran (TNSB) を用いて種々の観察を行 った[16]。その結果、最も良い結果が得られたの
は染料の質量濃度がおよそ $0.01 \%$ の時であった と報告している。また、Fig.9 に示すように、川路 は液膜内の複雑な多次元流れ（たとえば、波状流 やスラグ流のような2 次元性の強い流れ）を観察

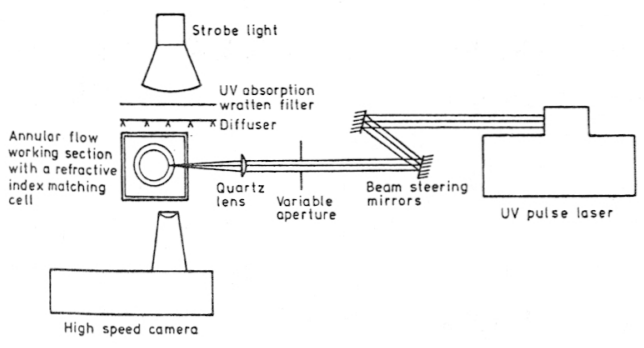

Fig.8 Optical System Using Photochromic Dye Tracer Method [15]

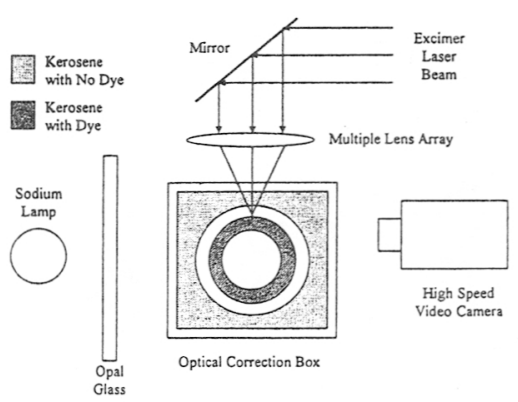

AXIAL VIEW

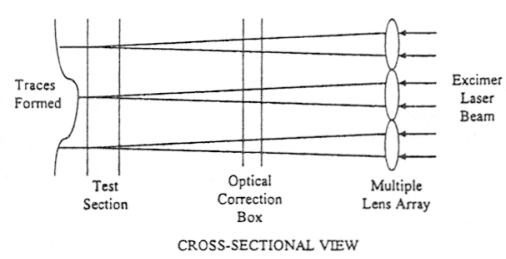

Fig.9 Photochromic Dye Method by Kawaji [16]
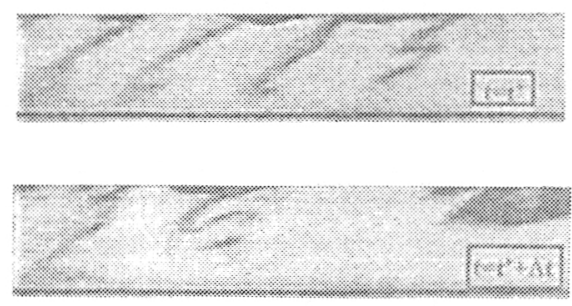

Fig.10 Vortex beneath a Disturbance Wave Captured by Photochromic Dye Method [16] 
するため、同時に 3 本の発色軌跡が見られるよう に光学系を設定した。こうした多次元性の強い流 れでは異なるレンズ系を通過してきた UV 光によ る線状の発色軌跡は互いに交差し、縞状のライン を描く。Fig.10 は自由落下液膜流の擾乱波の下に 形成される渦の運動を捉えたものである [16]。

Fig.8 やFig.9に示した方法は液膜内の流れの様 子を視覚的に観察したり、発色軌跡から定量的な 解析をするのに好都合であるが、液膜厚さの時空 間領域での多次元性を計測するには適していない。 筆者らはこの欠点を克服し、水平矩形流路内を流 れる薄い液膜流の 3 次元時空間特性や表面波の進 行速度を精度良く測定する蛍光染料法を提案した [17] (Fig.11)。

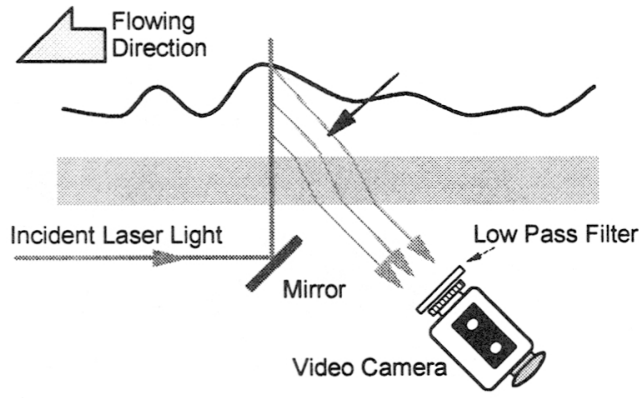

Fig.11 Fluorescence Dye Method for Multi-dimens ional Film Flow Measurement [17]

Fig.11において、作動流体である水に極微量の 蛍光染料ローダミン B を溶解させる。ローダミン $\mathrm{B}$ は波長 $200 \sim 600 \mathrm{~nm}$ の光で励起され $(517 \mathrm{~nm}$ で 最も強い)、 $590 \mathrm{~nm}$ の蛍光を発する。励起光に $\mathrm{Ar}$ ガスレーザーを使用し、レーザー光を遮断するフ イルターを用いれば、暗室状態下で容易に蛍光の みをカメラで撮影することが出来る。この測定で は、Ar ガスレーザー光を厚さ $0.1 \mathrm{~mm}$ のシート状 にして、透明アクリル製試験部底部下方から流体 中に導入した。蛍光の残光時間は数 $\mu$ 秒程度であ り、この間に流体が移動する距離はレーザーシー 卜の厚さに比べ十分小さい。ビデオカメラを試験 部下方に流れの上流側から 45 度の角度に設置し、 撮影する。液膜に起因する蛍光の強度分布を高速 ビデオで撮影し、コンピュータで二值化、画像解 析することで、流れの瞬時液膜情報が得られる。 液膜厚さ測定精度は約 $50 \mu$ 程度である。レーザー
シートを流れに直交して試験部に垂直に導入すれ ば、流れの任意断面の瞬時液膜厚さ分布が求めら れる。Fig.12 はこのようにして求めた流路断面内 液膜厚さ分布の測定例を示す。また、レーザーシ ートを流れに平行に導入すれば、得られた波高分 布（Fig.13）の等高線図の時間変化率から、等高 線の傾きとして波の進行速度が計算できる。この 蛍光染料法は多次元絶対測定法であり、較正の必 要が全くない点が大きな利点である。なお、Fig.13 の横軸、縋軸、高さ軸はそれぞれ経過時間、流れ方 向位置、液膜厚さ（0～ $5 \mathrm{~mm}$ ) である。

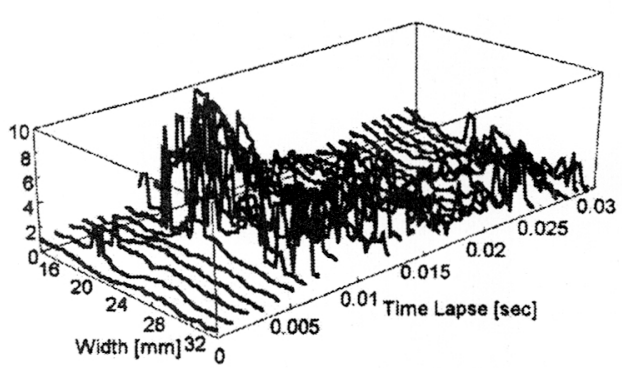

Fig.12 Time Sequence of Large Disturbance Wave over Channel Width Captured by Fluorescence Dye Method [17]

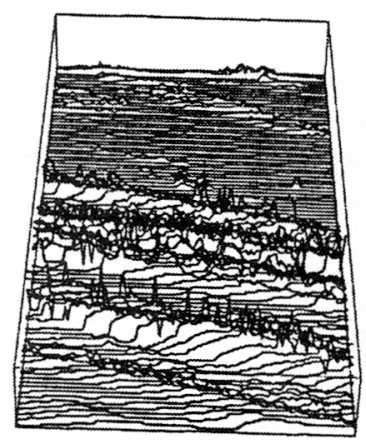

Fig.13 Bird's Eye View of Time Sequential Axial Movement of Waves [17]

\section{3.コンダクタンス法}

コンダクタンス法は一対の電極間にある流体の 抵抗変化から気液二相流の相分布の情報を求める 手法で、様々な方法が提案されている[1]。最も一 般的で、特別な較正を必要としないものに点電極 プローブ法がある。この点電極プローブを流路内 に多数設けて多点同時測定を行い、流路内 2 次元 
相分布の時間経過を測定する超多点プローブ法も 報告されている[18]。また、流れ方向の一定領域 内の平均的な液膜厚さを求める定電流法 [19]、流 路壁面上に一対の電極を埋め込んで、その周辺の 微小領域での液膜厚さを求める壁面プローブ法

(flush-mounted probe)、壁面に垂直に 2 本の細線 を平行に設置した 2 線プローブ法（parallel-wire probe） [20]、壁面プローブ法と 2 線法の中間的な フラッシュ・ワイヤー・プローブ法 (flush-wire probe）[21]などがある。点電極プローブ法では、 気液のそれぞれの相を $\mathrm{ON}-\mathrm{OFF}$ 二值信号として出 力するため、較正を要しない。その他の手法では、 流体物性や電極の幾何学的形状、電気的特性に出 力值が依存するため、実験の都度、較正が必要で ある。また、測定（検出）領域の大きさや感度分 布についての曖昧さがある。

\section{1 点電極プローブ法}

これは一般に電気抵抗式探針プローブのことで、 液体と気体の電気伝導度の違いを利用して、探針 先端が夜体中にあるか、あるいは気体中に存在す るかを電気信号として検出し、その気相（または 液相）存在時間率から局所ボイド率や液膜厚さに 関する量を求める。この探針部分を流れ方向に 2 〜 $5 \mathrm{~mm}$ 程度離して設置して複針式プローブを構 成すれば、両探針からの界面信号の時間遅れから、 波の進行速度を測定することもできる。Fig.14 は

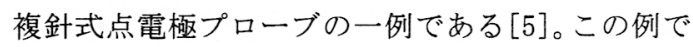
は探針部は先端を鋭く尖らせた直径 $0.3 \mathrm{~mm}$ の白金 線（またはステンレスの真直線も可）でできてお り、探針先端以外は合成樹脂で被覆、電気的に絶 縁されている。探針先端部とステンレス製の保護 管（図のキャピラリー管）が一対の電極を構成し ている。

Fig.15 に気相、液相を識別するための回路構成 と信号処理の原理を示す。探針先端が気液界面を

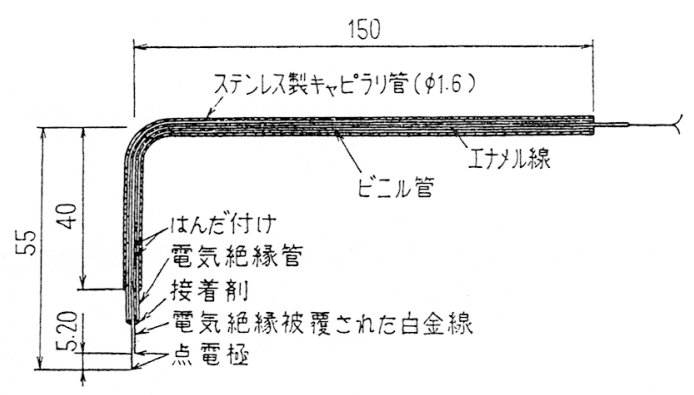

Fig.14 Schematic of Double Needle Probe [5]
貫通するとき、界面が変形し、出力信号が必ずし も $\mathrm{ON}-\mathrm{OFF}$ 的にならないので、信号の変化率及び DC レベルの䦭値の両方を用いて、二值化信号に変 換する。これにはアナログ的に処理する方法 [22] と、信号を $\mathrm{AD}$ 変換したあとコンピュータで処理す る方法とがある。液膜厚さを求めるには、点電極 が液相中に存在する時間割合の累積值を縦軸に、 壁電極面からの距離を横軸にとってプロットし、 液相存在時間率が一例として $95 \%$ の位置を最小 液膜厚さ、 $5 \%$ の位置を最大液膜厚さとして決定す る。平均液膜厚さは液相存在時間曲線の積分值の $50 \%$ の位置として求められる。

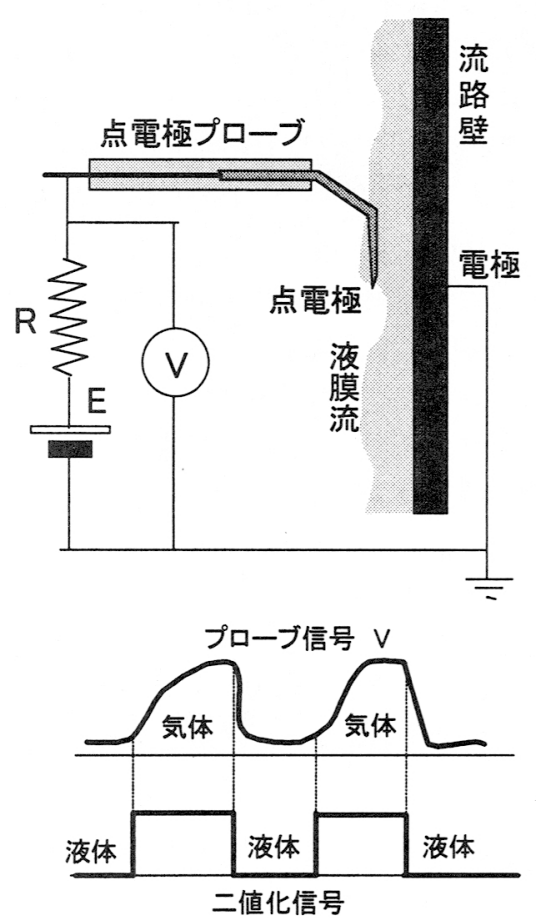

Fig.15 Basic Concept of Needle Contact Probe and Signal Processing

\section{2 超多点点電極プローブ}

これは世古口ら [18]によってなされたもので、 上に述べた点電極 (直径 $0.1 \mathrm{~mm}$ の白金線の先端を 角度 20 度に尖らしたもの)を、Fig.16示すように、 半径方向の 17 点を 1 ユニットとして、試験部（内 径 $25.8 \mathrm{~mm}$ の円管）周方向に 24 ニニット（うち 1 ユニットは円管中央にも点電極を配置)、計 409 本の点電極を流路断面に配置している。プローブ 
群を固定するステンレス箔と各点電極は対をなす 電極となっている。壁面に最も近いプローブは壁 面から $50 \mu$ の位置にあり、環状噴霧流の液膜構造 が測定できる。これら 409 本のプローブからの電 圧信号は $1 \mathrm{~ms}$ 毎に同時計測でホールドされ、順次 コンピュータに取り込まれ、処理される。Fig.17 は得られた擾乱波の様子を示したものである。

\section{3 定電流法}

これは深野ら[19]の考案によるもので、壁面に 設けられた電極間に存在する液膜厚さに依存する 電極間の抵抗変化を検出する場合、印加電流の電 極付近で電気力線分布が不均一になることに起因 する測定誤差を排除し、測定領域全域にわたる均 一な測定感度を保証する方法として定電流法が提 案された。この考案は 1971 年に遡る。Fig.18にお いて、試験部に取り付けられた $A 、 B$ 点がリング状 の真鍮製定電流用端子で、試験部の内壁面に面一 になるように埋め込まれている。用いる定電流值 は $0.1 \mu \mathrm{A} \sim 11 \mathrm{~mA}$ で、流れ方向の数ヶ所に設けら れた対の電位差測定端子から取り出された電位信 号は流体中での均一な電流密度分布を乱さないよ う、高入力インピーダンスの增幅器で増幅され、 $\mathrm{AD}$ 変換の後コンピュータで処理される。1 対の端 子間の電位差出力 $\mathrm{V}$ とその区間での平均のホール ドアップ (液相体積率) $\eta$ とは反比例の関係にあ り、既知のホールドアップク。に対する電位差 $\mathrm{V}$ 。 がわかれば、 $\eta=\eta 。\left(V_{0} / \mathrm{V}\right)$ として求まる。この定 電流法は後述の壁面プローブ法にも応用された。

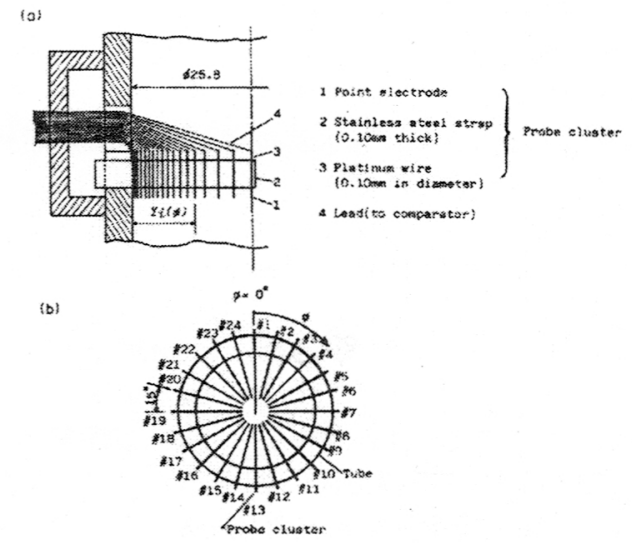

Fig.16 Design of Multi- Needle Contact Probes [18]

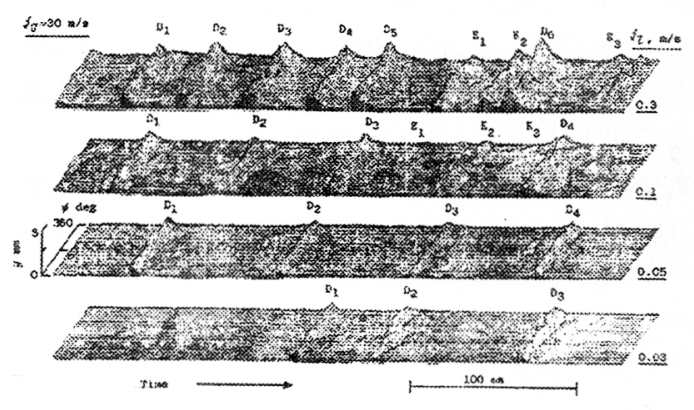

Fig.17 Disturbance Waves Captured by MultiNeedle Contact Probes [18]

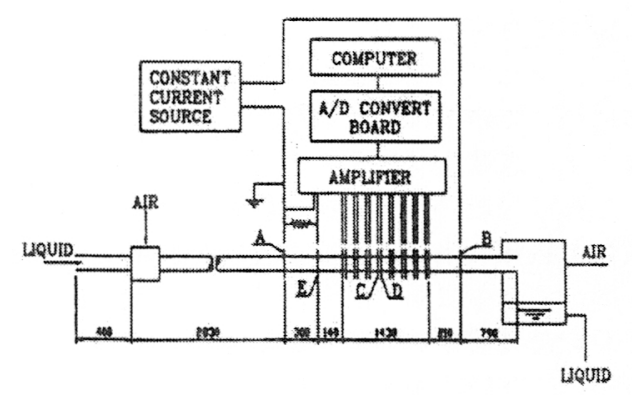

Fig.18 Constant Current Conductance Method [19]

\section{4 壁面プローブ法 (Flush-Mounted Probe)} 壁面プローブ法は 1 対の電極を流路壁面に面一 になるように埋め込んだものである（Fig.19）。こ のタイプのプローブには様々なデザインが報告さ れているが[1]、Coney [23]の理論解析及び実験結 果から、一般に液膜厚さが $2 \mathrm{~mm}$ 以上になると、測 定精度が著しく低下すると言われている。Fig.20 に代表的な電極のデザインを示す。

沸騰水型原子炉燃料集合体内の液膜挙動を空気 一水系で模擬した星出ら [24]の実験では、模擬然

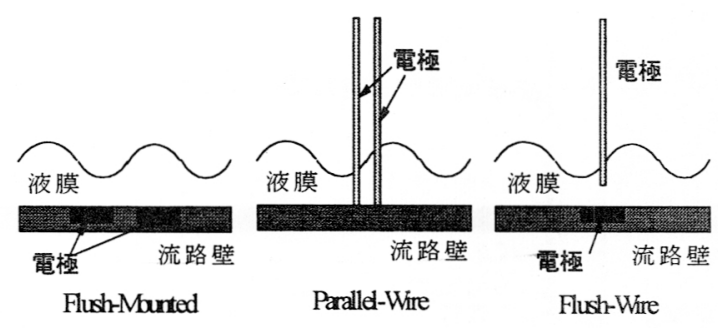

Fig.19 Flush-Mounted Probe and Wire Probes 


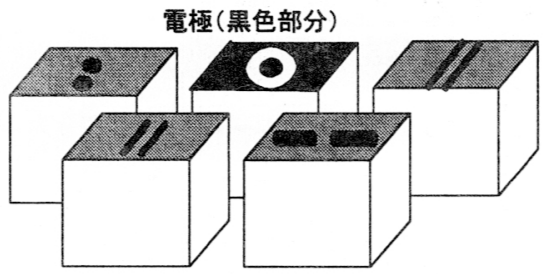

Fig.20 Various Designs of Flush-Mounted Conductance Probe [1]

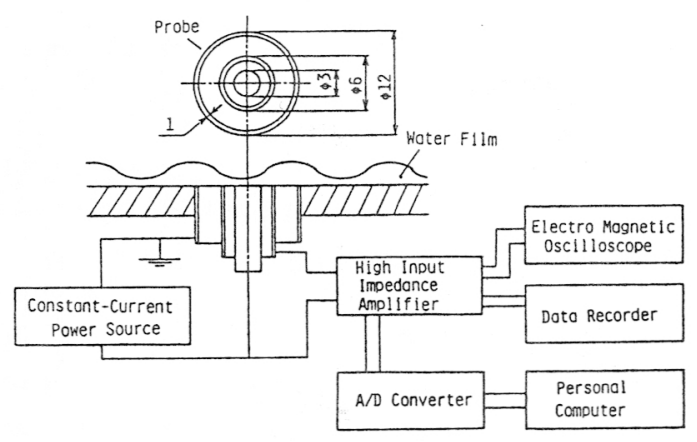

Fig.21 Constant Current System Applied for FlushMounted Conductance Probe [19]

料棒の外表面に壁面プローブを設け、 $0.2 \mathrm{~mm}$ 程度 の液膜厚さを測定している。なお、Fig.21 は深野 [19]による定電流型壁面プローブである。

\section{52 線式プローブ (Parallel-Wire Probe)}

壁面プローブは、電極間の電気力線の分布を考 えれば直ぐわかるように、液膜厚さが大きくなる と測定感度が大きく鈍る欠点がある。その限界は Coney の研究によれば $2 \mathrm{~mm}$ 程度が上限である。そ こで、 $2 \mathrm{~mm}$ を超える液膜厚さの測定にも適用でき るものとして、2 線プローブが考案された([20], [25] - [ 27]) (Fig.19 参照)。

2 線プローブは裸の 2 本の細線を壁面上に垂直 に、流れに直交して固定したもので、水の場合、 周波数が $100 \mathrm{KHz}$ 以上の交流ではアドミッタンス が無視できるので(Brown et al [27])、液膜の厚さに 依存して 2 本の細線間の抵抗が減少する。Koskie ら[20]は 2 本の細線の周りの電磁場を解析し、2 本 の細線の直径 $\mathrm{d}$ とその間の距離 $2 \mathrm{~b}$ としたときの、 検出感度を求めた。その結果を、全抵抗値の $90 \%$ 、 95\%、99\%を含む楕円領域の大きさについて、

Fig.22 に示す。この結果から概算すると、たとえ ば、棈円型の感度領域の長軸長さ 1 を $2 \mathrm{~mm}$ 、細線
電極の直径を $0.1 \mathrm{~mm} 、 2$ 本の細線間の距離 $2 \mathrm{~b}$ を $0.667 \mathrm{~mm} \quad(1 / 2 \mathrm{~b}=3)$ と仮定すれば、95\%感度領 域の短軸の長さは $1.4 \mathrm{~mm}$ となる。すなわち、ほぼ、 $2 \mathrm{~mm} \times 1.4 \mathrm{~mm}$ 程度の領域内の液膜の平均的挙動、 換言すれば、その程度の空間分解能をもつことに なる。このように 2 線プローブは壁面プローブに 比べて優れた分解能をもつ。しかし、一方では、 細線が流れを乱し、細線の後流部に渦を生じるた め、直径の大きな線は使用できない。その適正範 囲は $40<\operatorname{Red}<150$ とされている[28]。ここに、

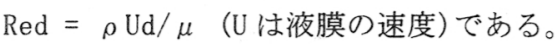

Fig.23 は Koskie らが試作した測定回路例である。 $100 \mathrm{KHz}$ 以上の高周波の交流では、流体のアドミッ タンスが無視できることから、Koskie らは周波数 $100 \mathrm{KHz}$ の交流を印加した。また、10KHz のカット オフ周波数のローパスフィルターを使用している。 2 本の細線電極間の電気抵抗が細線自身の電気抵 抗に比べ十分大きければ、出力と液膜厚さは一次 の関係を示す。

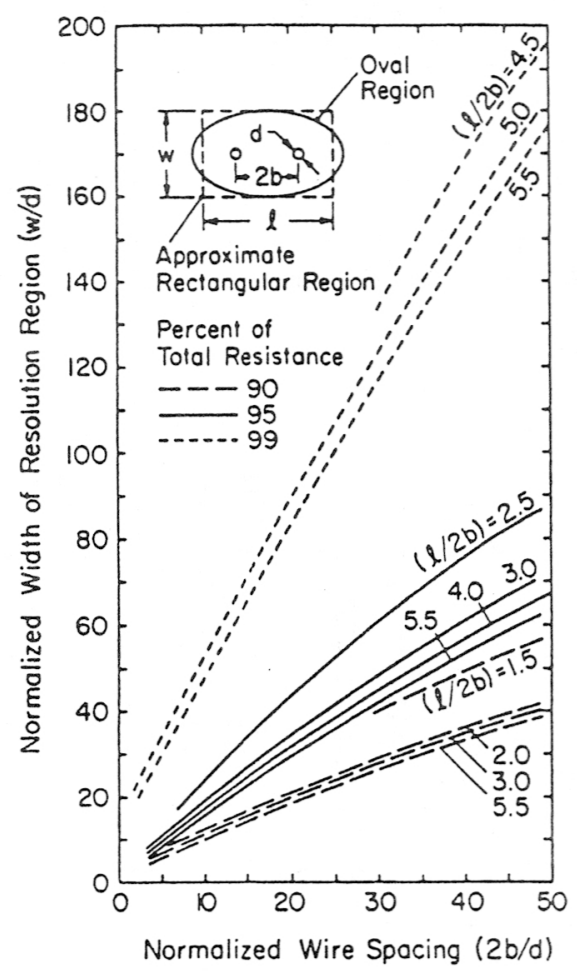

Fig.22 Resolution Region of the Probe as a Function of Wire Spacing [20] 


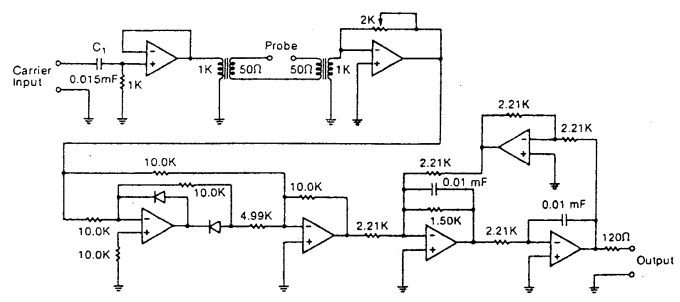

Fig.23 Wiring Diagram for Parallel-Wires [20]

\section{6 フラッシュ・ワイヤー法}

既に述べたように、2 線プローブはそれまでの 壁面プローブに比べて、液膜厚さが大きい場合に も適用できること、そして測定に倸わる感度領域 をある程度小さくすることに成功したものの、厚 さが $1 \mathrm{~mm}$ 程度以下の薄い流れ条件に対しての測 定精度が必ずしも十分ではなく、また、2 本の細 線が流れを乱すなどの久点がある。一般に、液膜 厚さが $0.1 \mathrm{~mm} \sim$ 数 $\mathrm{mm}$ 程度で変動周期が数 $100 \mathrm{KH}$ $\mathrm{z}$ 程度まで対応できる手法が好ましい。Kang \& $\operatorname{Kim}[21]$ は上述の欠点を克服すべく、Fig.19に示す フラッシュ・ワイヤー法（Flush-Wire Probe）を提 案し、Koskie らと全く同様な解析と実験を行った。 Fig.24 は壁面プローブ、2 線プローブ、フラッシ ュ・ワイヤープローブに対する感度解析モデル、

Fig.25 はその解析結果である。1mm 厚の液膜に高 さ $1 \mathrm{~mm}$ 、奥行き $3 \mathrm{~mm}$ 、長さ $8 \mathrm{~mm}$ の波を仮定している。

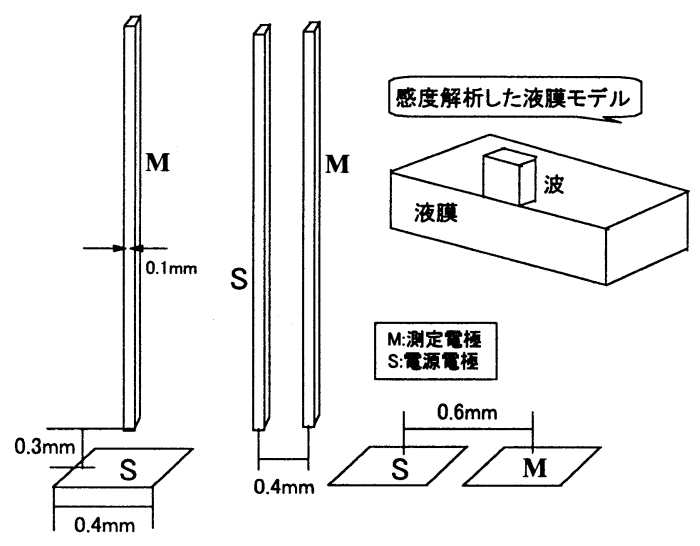

Fig.24 A Simulation Model for Sensitivity Analysis [21]

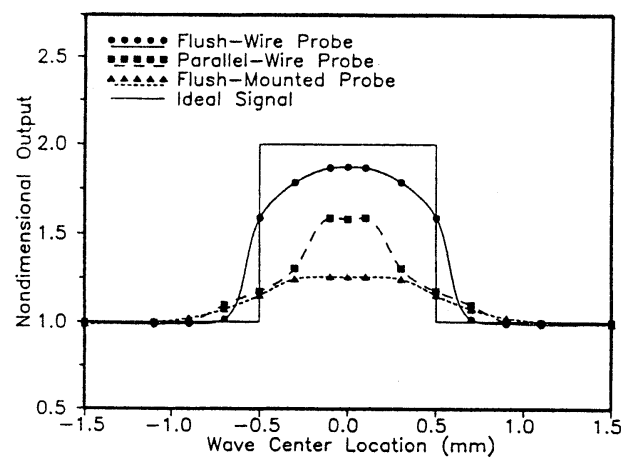

Fig.25 Result of Sensitivity Analysis for a Square Wave [21]

解析結果から、フラッシュ・ワイヤープローブの感 度がテストした 3 つの中で最も優れていることが わかる。原論文では試作回路も紹介されている。

\section{4. 光学的プローブ法}

フロンやハイドロカーボンのように液相、気相 の電気伝導度や誘電率が極めて小さく、また、そ れら物性の気液間の差が小さな流体に対してコン ダクタンスプローブを適用するのは困難である。 そのような流体に対しては光学的手法 (透明流体) や後述の超音波の利用が有利である。ここでは最 近開発された幾つかの測定方法について述べる。

\section{1 光ファイバ液膜センサー}

大場ら [29] の試作した光ファイバー液膜セン サーの原理を Fig.26に示す。ファイバー内を伝播 したレーザー光は液膜流を液側から透過し、液膜 表面で反射される。壁面に面一に埋め込まれたセ ンサーヘッドは送光ファイバーに受光の機能をも 持たせた単ファイバーからなり、液膜界面での後 方反射光の一部は、同じファイバーで受光され、 光検出器 (フォトダイオード) に送られる。この 際、光検出器の出力は、センサーヘッドから液膜 表面までの距離（局所液膜厚さ）と液膜界面の傾 斜角に依存する。傾斜角が大きくなると界面での 反射光の一部が検出できなくなるため、検出され る光強度、したがって、出力が低下する。傾斜角 がある場合の受光強度と液膜厚さの関係について 大場らは解析と実験を行い、両者の良好な一致を 得ている(傾斜角をパラメータとして)。ここでは、 ゼロ傾斜角となる液膜表面波の山と谷で最も強く 反射されるので、出力のピークとして観察される。 
この両者の值から平均液膜厚さ、波の振幅、波長 などを求める。この場合、ゼロ傾斜角における液 膜厚さに対する出力依存性を別途較正曲線として 求めておく。Fig.27 は大場らが用いた光学系の概 略である。

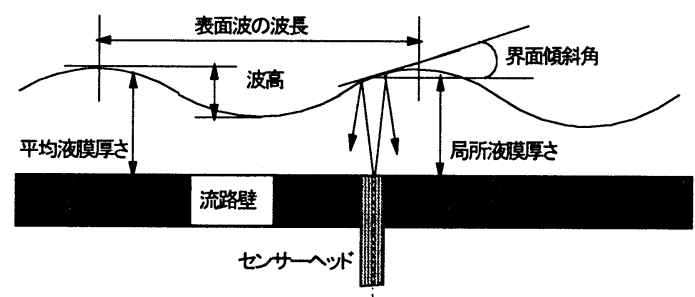

Fig.26 Fiber Optical Liquid Film Sensor [29]

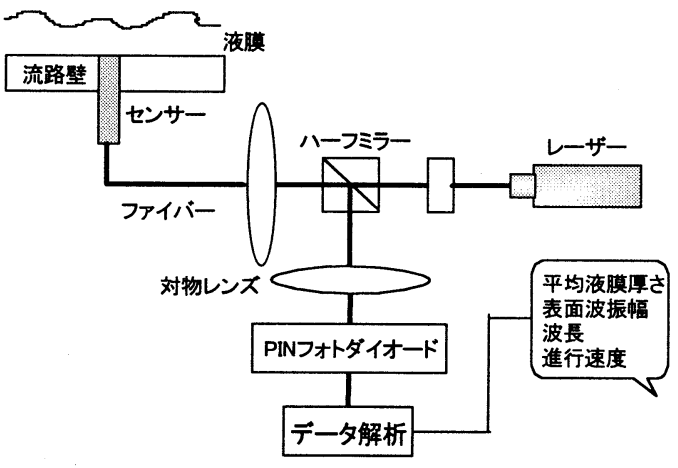

Fig.27 Schematic of Optical System [29]

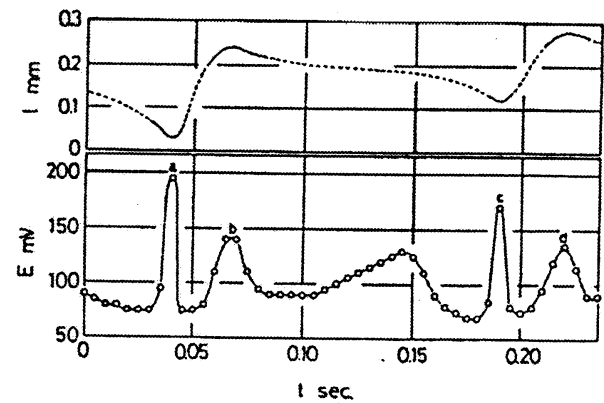

Fig.28 Optical Signals and Constructed Film Thickness Variation with Time [29]

また、Fig.28 は得られた出力信号から較正曲線を 用いて再現した局所液膜厚さの時間推移の予測曲 線である。大場らによれば、この光ファイバー液
膜センサーで測定可能な液膜厚さは $20 \mu \sim 3 \mathrm{~mm}$ 程 度となっている。大場らは、さらに、このセンサ 一を液膜の流れ方向にある間隔をおいて 2 ヶ設け、 その出力信号の相関から波の進行速度を測定して いる。

\section{2 レーザー変位計}

近年のエレクトロニスの急速な発展に伴って、 レーザー変位計は益々高性能化され、混相流計測 技術への展開が今後十分に期待できる。混相流研 究へのレーザー変位計の応用は、曲面を持つ放射 状の狭い流路の中を気泡が流動する際の局所ボイ ド率の測定と壁面での残留液膜を測定するのに筆 者が用いたのが最初である $[30,31]$ 。その後、液膜 測定用の超音波エコー法を開発する際、その比較 較正のためにキーエンス社の好意により、当時 30 数万円もしたレーザー変位計 (LB-40 型) (分解能 $2 \mu$ ）を借用して液膜の測定を行い、開発途上の超 音波エコー法（後述）や点電極法による測定結果 と良い一致を得た $[32,33]$ （Fig.29）。後に、賞雅 ら[34]が液膜測定に用いた高性能レーザー変位計 が開発されたが, 数 $100 \mu$ 数 $\mathrm{mm}$ 程度の液膜厚さ を求めるには、当時のものでも十分である。Fig.30 にその測定原理を示す [35]。

原理は以下の通りである。発光ダイオード (LED) の光をレンズを通して細く絞り対象物に照射し、 拡散した反射光を受光レンズにより光位置検出素 子上にスポットとして結像させる。対象物が変位 すると、このスポットが移動し, その移動量は対 象物の変位にほぼ比例する。このスポットの位置

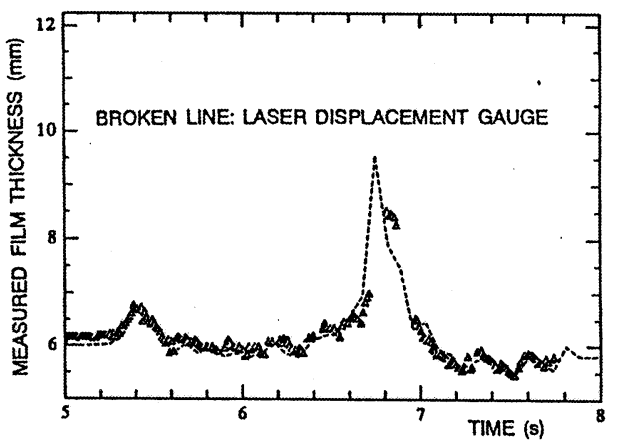

Fig.29 Comparative Representation of the Results of Film Thickness Measurements with Laser Displacement Gauge and Ultrasonic Transmission Technique [32] 


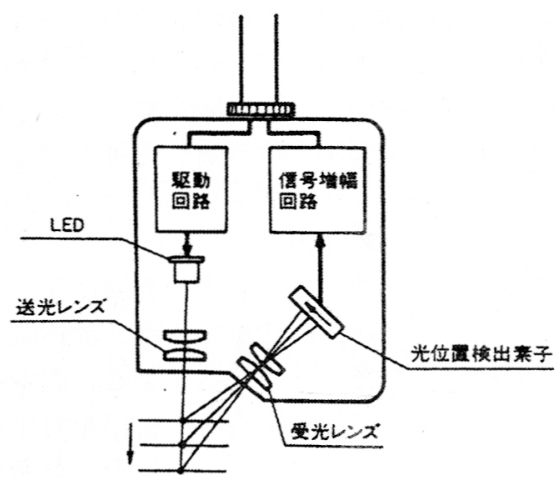

Fig.30 Principle of Laser Displacement Gauge [35]

を光位置検出素子が電気信号に変換し、コントロ 一ラ内の演算回路により、対象物の反射率とは無 関係な変位出力が得られる[35]。この原理を利用 して液膜厚さを測る場合、流路壁が透明材であれ ば液側の壁の背後にレーザー変位計を設置するこ とが可能である。同様に気相側からも液膜厚さを 測定することも出来る。後者の場合、気液界面の 位置を直接測定することで液膜厚さを知る方法と、 液相側の壁の内面での反射波が気、液相での屈折 率の違いから、液相の深さに応じて変位計で検出

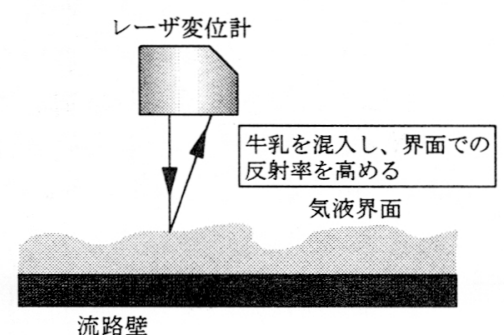

（a）気液界面反射利用

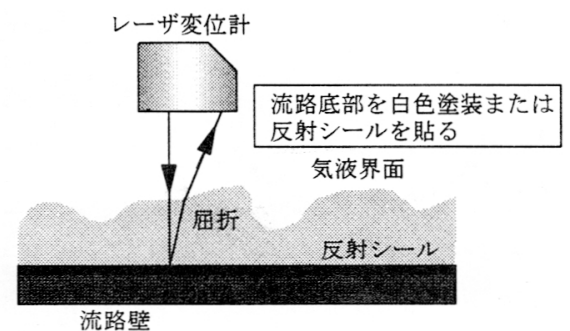

(b) 底面反射利用

Fig.31 Front Scattering of Laser Beam for Liquid Film Thickness Measurement
される位置が異なることを利用して、液膜厚さを 求める方法の 2 つがある。Fig.31 はそれぞれの場 合について検出効率を高めるための工夫を示した ものである。いずれの測定においても、予め静止 液膜を用いて作成した較正曲線から液膜厚さを求 めた。最近、賞雅ら $[34,36]$ は高精度レーザーフォ 一カス変位計 (Laser Focus Displacement Meter モデ ル LT-8100）（LFD）を用いた高精度液膜測定法を 開発した。賞雅らが使用したレーザー変位計は先 に筆者らが用いたと同じキーエンス社製のもので あるが、異なる原理によるものである。Fig.32に 示すように、半導体レーザーから発振された円錐 型ビームはハーフミラーと対物レンズを透過した あと，対象物の表面に入射する。対象物からの散 乱光は入射光と同じ経路を逆に迻り、対物レンズ を通り、ハーフミラーで反射され、ピンホールに 至る。対物レンズは音叉で振動する。音叉の振動 自身は位置検出素子によりその位置が検出される。 対象物に入射レーザービームの焦点が合った時刻 の反射ビームは、ピンホールの後ろにある光検出 素子で検出される。このように、音叉による対物 レンズの振動でレーザビームの焦点が対象物にあ った瞬間の時間が光検出素子で検出され, そのと きの音叉の位置検出から、対象物の位置の変化が 求められる。賞雅らが用いたレーザーフォーカス 変位計のビームスポット径は $2 \mu$ 、対象物の位置

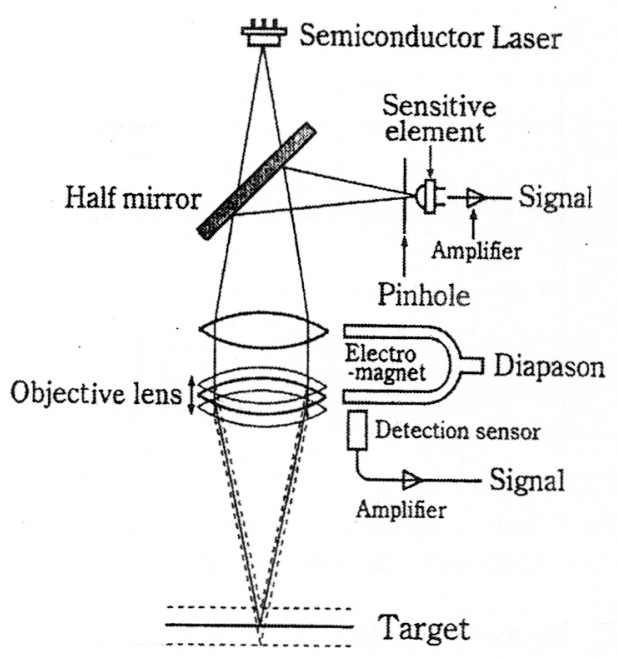

Fig.32 Principle of High Performance Laser Focus Displacement Meter [36] 


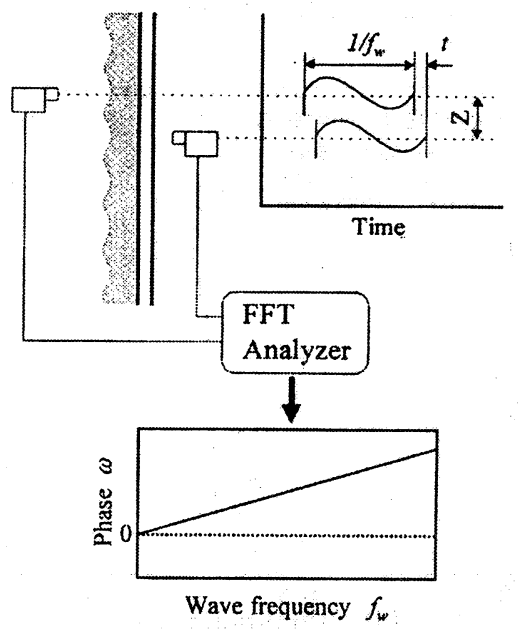

Fig.33 Wave Velocity Measurements with Two LFDs [36]

変化測定のダイナミック・レンジは $28 \pm 1 \mathrm{~mm}$ 、空 間解像度は $0.2 \mu$ である。時間解像度は $1.4 \mathrm{KHz}$ である。また、賞雅らは Fig.33 に示すように、2 つの変位計 (LFD) を流れ方向の 2 点に設置し, 波 の進行速度も計測している。その場合の測定可能 な液膜表面波の周波数は $175 \mathrm{~Hz}$ 以下である。

Fig.34 は賞雅らによる水の自由落下流実験にお ける液膜厚さの時間変動の測定例である。

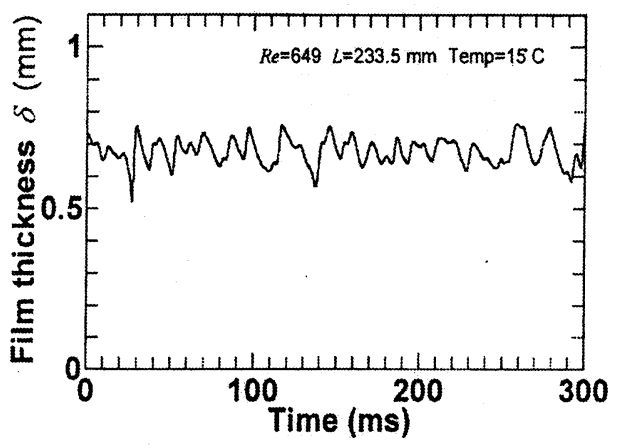

Fig.34 Time-Varying Film Thickness Measured by LFD [36]

\section{5. 超音波法}

超音波を用いた液膜測定法には超音波エコー法
と超音波流速計法がある。前者は、潜水艦のソナ 一として、あるいは超音波探傷器として固体物質 中のボイドの検出に用いられてきた。挆傷器の用 途に用いられる超音波の周波数は $200 \mathrm{MH} \mathrm{z}$ 程度の 高周波であり、その空間分解能 (半波長) は物質 にもよるが数 $\mu$ 程度である。このような高周波の 超音波は一般に上述のように優れた空間分解能を 持つが，液体中では音響エネルギーが急速に減衰 する久点がある。そのため，気液二相流計測で用 いられるのは $20 \mathrm{MH} \mathrm{z}$ 以下が多い。後者は超音波の ドップラーシフトを利用して流れの局所速度場の 測定に用いられているものと同じである。

\section{1 超音波エコー法}

Ultrasonic Echo Technique または Ultrasonic Transmission Technique ともいう。超音波が媒質 中を伝播するとき、音響インピーダンス（密度 $\mathrm{x}$ 音速）の異なる媒質境界で反射する性質がある。 魚群探知機はその応用である。液体から気体に向 かって超音波が進行するとき、気液界面で音響工 ネルギーはほぼ $100 \%$ 反射される。この性質を利 用して気液界面の位置を測定する。超音波エコー 法の気液二相流研究への応用は 1981 年に既に Banerjee \& Lahey [2]によって「気液二相流研究へ の展開は有望である」と記述されており、ボイド 率測定系への応用例が示されている。液膜測定へ の応用として、Chang らによってスラグ気泡周り の液膜測定がなされたが[37,38]、特に大きな発展 は見られなかった。ここでは、超音波エコー法の 測定原理の概略と、最近, 筆者らが開発した超高 速多次元液膜測定法([39] - [41]) について述べる。

Fig.35 及び Fig.36 は一般的な超音波エコー法に よる液膜厚さ測定系の概略と、その時に得られる エコー信号の様子を示したものである。トランス デューサから出た超音波は、トランスデューサ自 身の内表面、流路外壁、流路内壁と液膜流との境 界面、液膜表面（気液界面）のいずれにおいて反 射する。Fig.36のピーク A、B、C、D はそれぞれに 対応したものである。たとえば，ピーク D は超音 波がトランスデューサを出てから気液界面で反射 して再びトランスデューサまで戻る往復時間であ る。従って、ピーク C とピーク D の時間遅れ(飛行 時間)を $\Delta t$ 、液膜の厚さを $\delta$ 、液膜中での音速を $C$ とすれば、 $\delta=C \Delta t / 2$ で与えられる。常温の 水中での音速はほぼ $1500 \mathrm{~m} / \mathrm{s}$ であるから、液膜中 での超音波の飛行時間 $\Delta t$ を測定すれば、瞬時の液 


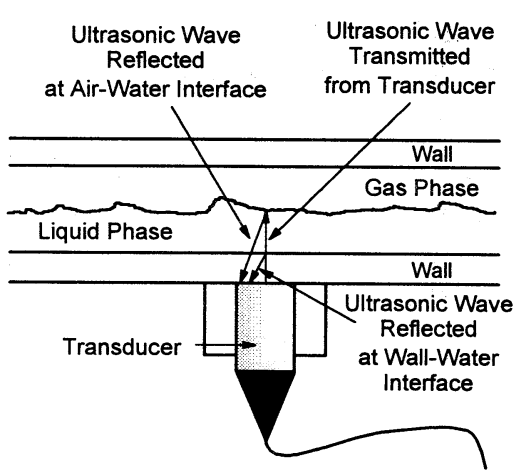

Fig.35 Principle of Ultrasonic Transmission Technique for Liquid Film Thickness

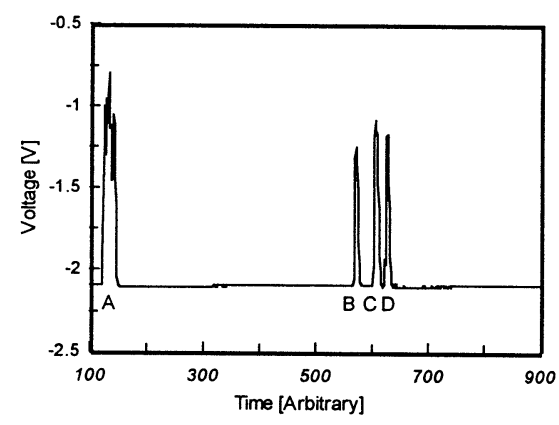

Fig.36 Echo Signals Originating from Boundaries

膜厚さが求められる。使用する流体中での音速は 既知の距離を飛行する時間から簡単に実験的に求 められるから、超音波エコー法は、レーザー変位 計などと違って全く較正の必要のない絶対測定で ある。従来の超音波エコー法の欠点は、この方法 が本質的には point measurement であり、空間領 域での多次元測定が出来ないことである。この欠 点をある程度克服する手法は、マルチプレキサな どを用いて複数のトランスデューサを電気的に切 り替えて測定し、それぞれの值を適当に時間軸に 対して補間して、多次元情報を得ることである。 もう1つの実用的な方法を以下に述べる。

たとえば沸騰水型原子炉炉心の安全性を確保し たり、燃料の高性能化を図る上で、燃料集合体を 構成する各サブチャンネル内の燃料棒周りに形成 され、スペーサの影響を受けると考えられる液膜 流の時空間領域での多次元挙動の知見が求められ ている。このような場での測定を対象として筆者 らが考案したのが Fig.37に概略を示す超高速回転

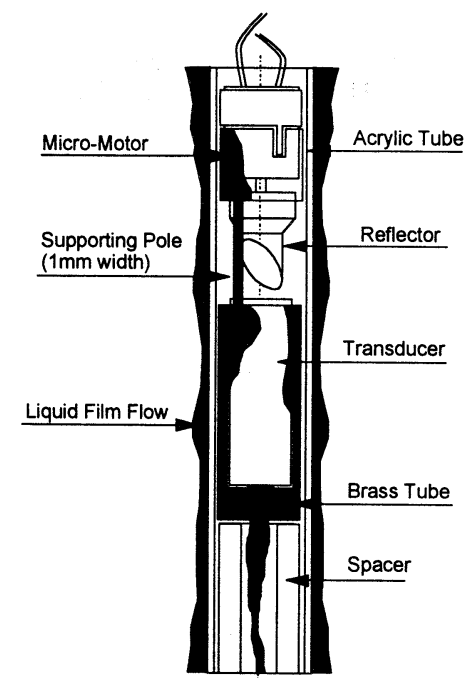

Fig.37 Schematic of Ultrasonic Transmission Technique with a Rotating Reflector [39-41]

リフレクターを備えた測定系である（[39]-[41]）。

燃料棒を模擬したアクリル製中空円柱の内部に、 超音波測定系を封入したもので、内部の空間は超 音波の伝播を可能とし、音響エネルギーの損失を 少なくするため水で満たされている。液膜流はこ の円柱の外周部を流れる。リフレクターは超音波 を効率的に反射する軽量のアルミ製である。その 先端面はトランスデューサからの超音波の伝播方 向に対し 45 度の角度を持たせた平面である。これ により超音波の伝播方向を 90 度変化させ、円柱の 半径方向、すなわち、液膜厚さ方向に伝播させる とともに、気液界面 (液膜表面)での反射波を再び トランスデューサの受感部に戻すことができる。 このリフレクターはマイクロモータにより 20,000 rpm の高速で回転する。その結果、僅か 3 ミリ秒で周方向を 1 周し、円柱表面の周方向の瞬 時液膜厚さ分布を効率的に測定することが出来る。

用いた超音波トランスデューサの周波数は $10 \mathrm{MHz}$ で、発振周期は $10 \mathrm{KHz}$ である。反射波信号 は分解能が每秒 10 メガサンプルの $\mathrm{AD}$ 変換ボード に送られ、毎秒 10000 個の反射波を処理する。超 音波は音響レンズで収束され、気液界面でおよそ 直径 $0.9 \mathrm{~mm}$ 程度である。液膜厚さ測定の精度は超 音波の半波長で制約され、10MHz に対して水中で は $75 \mu$ である。 $50 \mathrm{MHz}$ の超音波を使用すれば、分 解能を $15 \mu$ 程度まで下げることが出来る。また、 
周方向の空間分解能はサンプル数の関係から 1.5 $\mathrm{mm}$ 程度である。流れ方向の空間分解能は、液膜の 速度を $0.5 \mathrm{~m} / \mathrm{s}$ とすれば、 $1.5 \mathrm{~mm}$ となる。これは、 回転数の向上、発振周波数を $20 \mathrm{KHz}$ まで高めるこ と、リフレクター形状を改良することなどで、

$0.5 \mathrm{~mm}$ 程度まで改善できる。スキャン時間も従っ て 1 2ms 程度まで短くできる。現在最も高速のX 線 CT スキャナー[42]が $0.5 \mathrm{~ms}$ であることを考える と、相当高性能といえる。

Fig.38 は得られた模擬燃料棒表面の周方向液膜 厚さ分布の時間変化の鳥瞰図である。Fig.17 に相 当するものである。この測定では平均液膜厚さが $0.1 \mathrm{~mm}$ のオーダーで非常に薄く、大きな擾乱波は 見られず、3 次元的なペブル波が計測されている。 この超音波エコー法を利用して液膜表面波のサイ ズ分布や周期、波高分布など基本的な特性を計測 することが出来る。
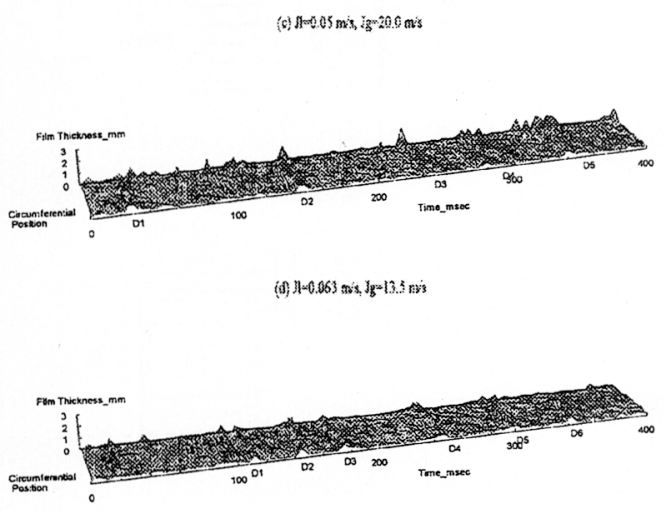

Fig.38 Bird's Eye View of the Circumferential Distribution of Local Instantaneous Liquid Film Flow around a Rod

\section{2 超音波流速計}

単相流の計測で使用される超音波ドプラー流速 計（UVP）（Takeda[43]）を用いて、液深が 10 数 $\mathrm{cm}$ と比較的大きな液膜流（波状流）の瞬時の液膜 厚さと液膜内速度の瞬時 2 次元測定が中村らによ って報告されている $[44]$ 。この測定原理を Fig.39 に示す。液膜内の液の速度分布は流体中に含まれ る微小な粒子（比重 1.01 、直径 $0.1 \sim 0.5 \mathrm{~mm}$ のポ リスチレンを使用）による超音波の反射波のドプ ラーシフトから求めるため、図に示されるように
超音波流速計は流路垂直方向からある角度 $\theta_{1}$ に おかれる。また、液速度測定の流れ場の局所位置 は超音波の反射時間の遅れから、飛行時間 (time of flight）法によって求める。気液界面の位置の検出 は前節で述べたのと同様である。この時、測定可 能な最大速度 $V \max$ と空間分解能 $L$ は次の関係 を満たす [43]。

$$
V \max L<C^{2} / 8 f
$$

ここに、C、 $f$ は流体中での音速、超音波の周波 数である。この測定系での空間分解能は $0.75 \mathrm{~mm}$ である [44]。 Fig.40に測定された瞬時の液膜厚さ と液膜内速度分布の時系列を示す。

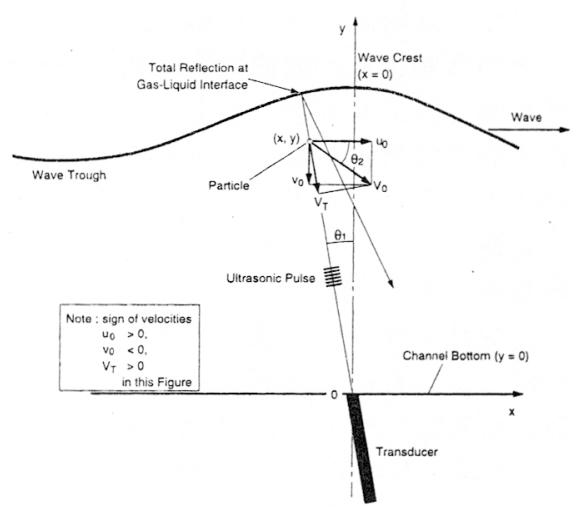

Fig.39 UVP Measurement Configuration for Wavy Flow [44]

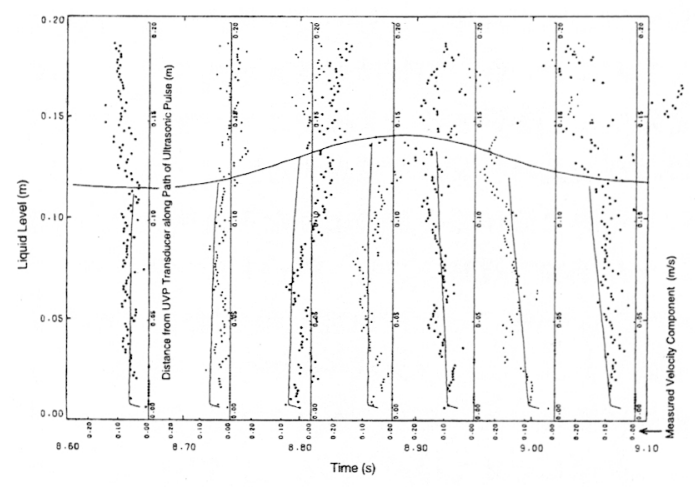

Fig.40 Time-Varying Film Thickness and Velocity Profiles [44]

\section{3 超音波 C T 法}

超音波 C T 法は医療診断などで日常的に使わ れており、気液二相流現象の多次元特性の可視 
化技術としての応用の可能性を否定するもので はないが、解決すべき課題も多い。たとえば、前 述したように、音響エネルギーのほぼ $100 \%$ 近 くが気液界面で反射されるため、超音波の伝播 経路上に複数の気液界面が存在するような場合 （たとえば、気泡分散流）には最初の気液界面 で超音波が反射され、それ以上の伝播が妨げら れる。そのため、正確な可視化が不可能である。 さらに、多重反射の問題もある。また、液膜流 では高い空間・時間解像度が要求されるが、それ をどのようにクリアーするかが課題である。

\section{6. 放射線を用いた可視化手法}

X線やガンマ線、中性子、陽子などの放射線を 用いた可視化手法が様々なところで試みられて いる。また、放射線ではないが、核磁化の空間 位置をその歳差運動の周波数と位相で識別する 核磁気共鳴 (NMR) など、もともと医療での 放射線診断や放射線治療、放射化学、非破壊検 查等々で用いられてきている手法が気液二相流 計測に急速にとりいれられつつある。既に許さ れた紙数を大幅に超過しているので、ここでは 中性子ラジオグラフィー法とその関連について 簡単に触れることにする。

混相流可視化手法の 1 つとしての中性子ラジオ グラフィーは、日本では、京大炬、神戸大学、関 西大学、日本原子力研究所等の研究者を中心に研 究報告がなされている（たとえば、[45]-[48])。

これは物質内の中性子の減衰特性が物質により 異なることを利用したもので、熱中性子では概し て水素などの軽い物質ほど減衰が大きく、一般の 金属はよく透過する（X線やガンマ線は逆に金属 のような重(物質ほど減衰する)。従って、光学的 に不透明な流体や金属のような不透明流路内の流 れを非接触で観察できる。Fig.41に中性子ラジオ グラフィー法の一般的原理を示す[45]。試験部を 通過したビームはコンバータで中性子画像から光 画像に変換され、ミラーを介して高感度カメラま たは高速ビデオで撮影される。空間解像度や時間 分解能の点で改良の余地が残されているが、多次 元計測についてはC T 法が試みられ成果を挙げて いる[47]。たとえば、Fig.42 は竹中ら[47]によっ て $4 \times 4$ 本管群体系に対して中性子ラジオグラフ イーを用いたC T法によって求められた流路断面
内の液相分布図である。この結果は液滴、液膜を区 別するものではなく、得られたデータから薄い液 膜を識別する技術の開発は今後の課題である。一 方、高速中性子の減衰特性の物質依存性は熱中性 子とは逆の傾向を示し、原子番号の大きな物質ほ ど減衰する [46]。従って、熱中性子と高速中性子 とを併用し、それらの特長を使い分けることによ って、複雑体系下での高度な測定を行う試みもあ る(竹中ら $[48])$ 。

中性子が電気的に中性であるのに対して、陽子 は荷電粒子であり、電磁場を用いて容易に収束さ せることができるため、中性子に比べ $2 \sim 3$ 桁ほど 陽子線のフラックス（束）を大きくすることが出

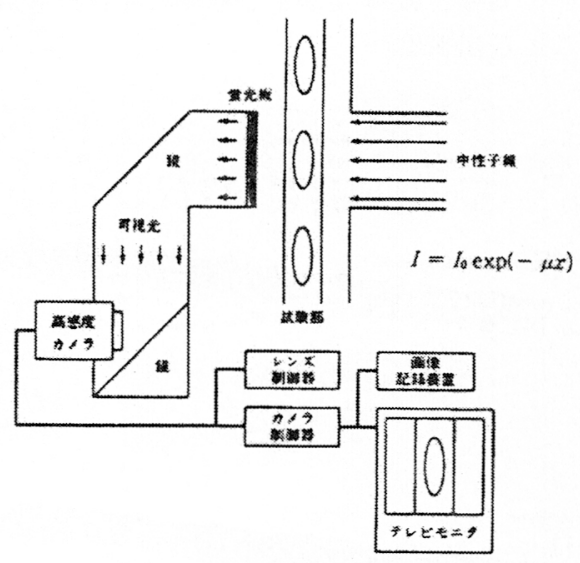

Fig.41 Concept of Neutron Radiography [45]

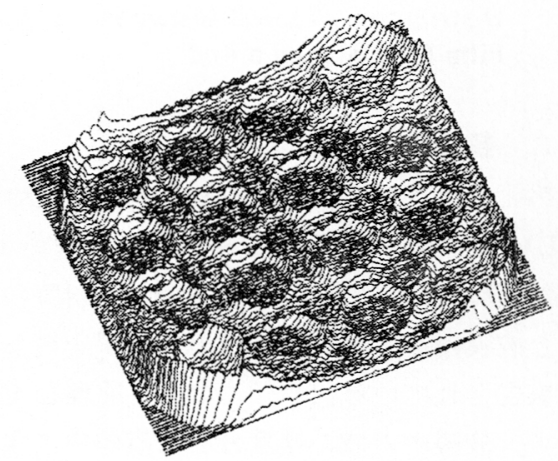

Fig.42 Liquid Fraction Distribution in $4 \times 4$ Rod Bundle Measured by Neutron Radiography Using a CT Method [47] 
来る。従って、陽子線ラジオグラフィー法は中性子 ラジオグラフィーに比べ、より高速現象への適用 性を有し、かつ、空間解像度の点で優れていると言 える。しかし、陽子線の金属透過特性は中性子に 比べ格段に劣るため、細管や狭险流路などへの適 応に限られる [49]。

X線、ガンマ線、中性子または陽子線を用いた C T法やラジオグラフィ法のいずれも、現状では、 薄い液膜を時空間領域で精度良く定量的に評価、 測定するのは困難であり、他の手法と併用するこ とによって、それらの特長が生かされると思われ る。今後の課題であろう。

\section{7. 液膜流量測定法}

液膜流量測定法はやや古典的とも言える従来 型の方法 [1]以外の有効な手法は見当たらない。 無論、液膜厚さが大きい場合には 5.2 節で述 へた超音波流速計や光発色性染料法による液膜 内速度分布の測定から液膜液流量を算出するこ とは可能であるが、一般的には液膜が薄く、液 膜内速度分布を精度良く測定するのは困難であ る。液膜厚さ及び圧力損失の測定結果を用いて 液膜流量を算出する方法（いわゆる Hewitt らの Triangular Relationship [12]）もあるが、実験的 には壁面全周に設けたスリットや小孔群、多孔 質壁などから直接液膜を抽出する film removal method が主であり、多くの研究者がこの手法を 用いてきた [1]。Fig.43に一例を示す[50]。

液膜抽出法で液膜流量を求める際には、スリ ットであれ、多孔壁であれ、気液が同時に抽出 されるので気液を分離する。この時抽出される 液流量を気相流量に対してプロットすると、抽 出される液流量がほほ一定となる plateau が存 在する。このときの一定值が液膜流量である。

Hewitt[1]によれば、スリット法は大きな擾乱波 が通過する場合、抽出漏れが生じる可能性があ ること、一方、多孔質壁はこの部分を波が通過 する場合に、その波高を徐々に減少させつつ最 終的に抽出されるため、流れに与える負荷が少 ない等の点で、多孔質壁の方が優れていると結 論している。一方、Leman ら[51]によれば、完 全な film removal を行うには抽出部を少なくと も 80〜100mmにする必要がある。ただし、気相 主流中の液滴エントレーメントが大きい場合に は、液膜抽出部にある液膜上に気流中の液滴が
付着するので注意する必要がある。また、下降 流に適用する場合には多孔壁の下端でフラッデ イングし易いので注意する必要がある $[1] 。$

Fig.44 は流路内壁に沿う局所液膜流量分布の 測定に film removal 法を適用した例である[52]。 これは水平流路内壁の一部にフィンを設け、こ の小さなセグメント内の液膜を抽出する設計と なっている。周方向の分布は周方向に管を回転 させて測定する。

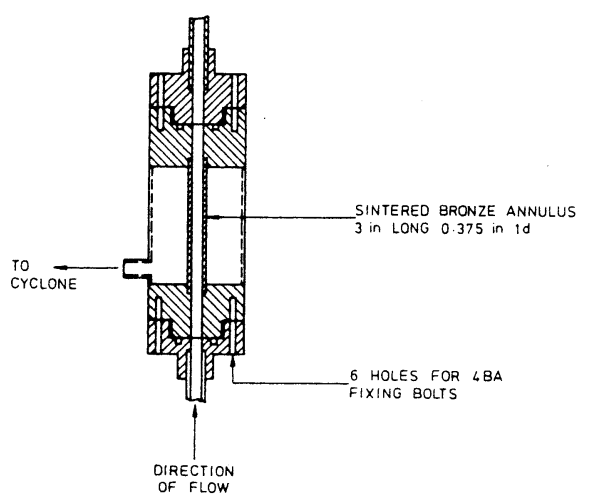

Fig.43 Porous Wall Film Extraction Device [50]

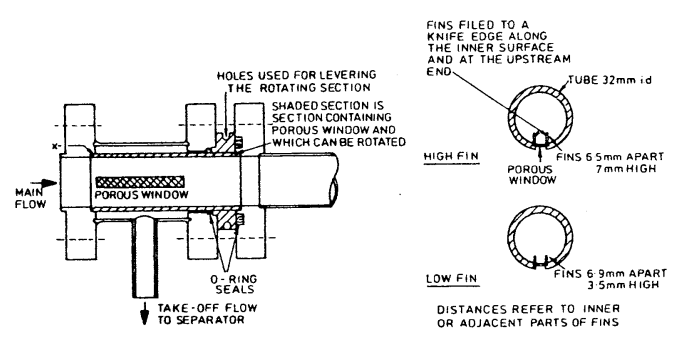

Fig.44 Local Film Flow Rate Measurement [52]

\section{8. 壁面せん断応力測定法}

液膜流における壁面せん断応力、とりわけ、瞬時 局所特性を測定する方法にはflush-mounted type の hot-film anemometry probe あるいは電解プローブ (Electro-Chemical Method) が有効である。これら の概略を紹介する。

\section{1 ホットフィルム・プローブ法}

Fig.45 は flush-mounted type のホットフィルム・ プローブの一例である[53]。センサー部分を試験 部内面と面一にし、センサー部分の長さ方向が液 
膜流の主流方向と直交する向きに設置する。ホッ トフィルムに電流を流し加熱するとき、ホットフ イルムは境界層内の流れによって冷却される。境 界層内の流れが壁面せん断応力に依存することか ら、通常の流速測定用のホットフィルムと同様に、 アネモメータ出力が壁面せん断力の関数となる。

いま、定温度型アネモメータ（Constant Temperature Anemometry) を用いるとすれば、壁面せん 断応力 $\tau$ と出力 $E$ との間には、次の関係がる。

$$
\ll E^{2} \gg=\mathrm{A}+\mathrm{B} \ll \tau^{1 / 3} \gg
$$

ここに、《》は時間平均、A、Bは定数で、較正 によって求めるか、または、リニアライザーを用 いてEとての関係を線形化する。較正に際しては 流れが十分発達した領域で、ホットフィルムプロ 一ブ出力と別の方法で測定した圧力損失から求め た壁面せん断応力との関係をプロットして、A、 Bを決定すればよい。Fig.46 は萩原[54]が較正に 用いた装置図である。過度現象時においても上の 関係が成り立つものとして、瞬時局所的な壁面せ ん断応力が求められる。なお、ホットフィルムプ ローブのセンサー部分が加熱されるため、そこで 流体中の溶存ガスが脱気泡となり、測定に支障を きたすことがある。そのため、オーバーヒーティ ング比 (加熱時のプローブ抵抗と非通電時のプロ ーブ抵抗の比）は測定感度を鈍らさない程度に出 来るだけ小さな值（通常 1.10 程度以下）に設定す ることが大切である。また、污れの影響も大きい ので注意する必要がある。

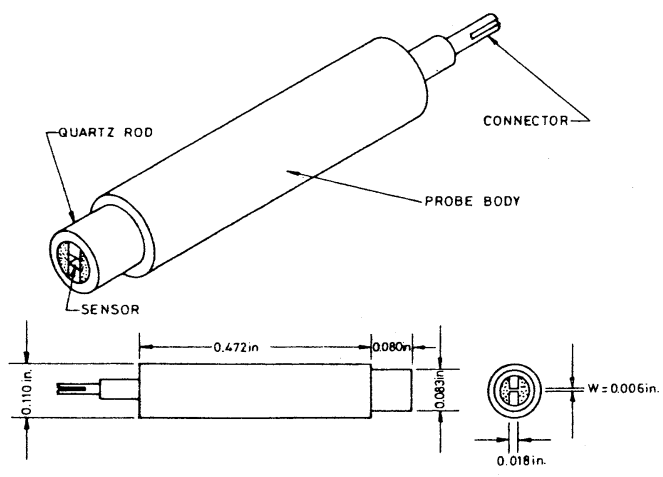

Fig.45 Hot Film Probe Used for Wall Shear Stress Measurement [53]

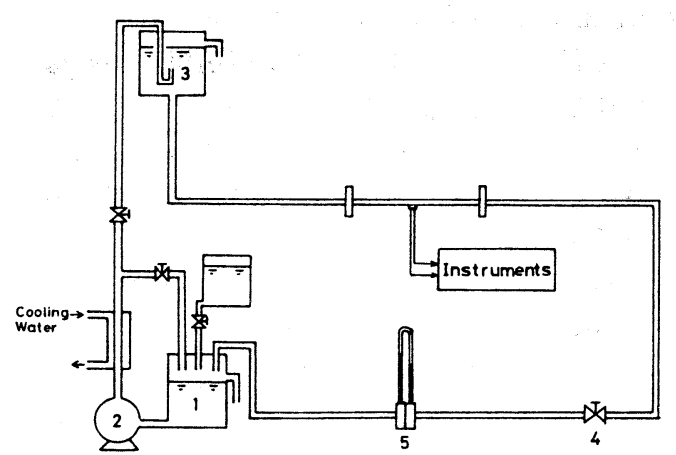

Fig.46 Calibration System for Hot Film Probe [54]

\section{2 電解プローブ法}

電解プローブ法についての詳しいレビューは水 科[55]によって、また、概要は Hewitt[1]によっ てもまとめられているので、参照するとよい。基 本的には電解質を微量含む流体が壁面に面一に埋 め込まれた $1 つ の$ 電極と他の電極との間で電解反 応 (物質伝達)を起こし、生成物であるイオンが生 じる。2つの電極のうち物質伝達係数を測定する 方の電極が壁面せん断応力測定用の電極を構成し、 他の 1 つの電極は物質伝達に係わる電流值を拘束 しない程度に十分大きくとられる。

通常、電解反応としてはフェリシアン/フェロシ アン反応 (ferricyanide / ferrocyanide reaction) が利 用される。電極材としては一般に陰極にニッケル が用いられる。物質伝達測定用の陰極と陽極では 次の化学反応が生じている。

陰極 : $\mathrm{Fe}\left(\mathrm{CN}_{6}\right)^{3-}+\mathrm{e} \rightarrow \mathrm{Fe}\left(\mathrm{CN}_{6}\right)^{4-}$

陽極 : $\mathrm{Fe}\left(\mathrm{CN}_{6}\right)^{4-} \rightarrow \mathrm{Fe}\left(\mathrm{CN}_{6}\right)^{3-}+\mathrm{e}$

電解の電圧を上げていくと、陰極面のフェリシ アンイオン濃度が低下し、ついにはゼロになる。こ れ以後に流れる電流は境界層を通してのフェリシ アンイオンの拡散に支配され、電圧によらず一定 の值に落ち着く $[1]$ 。

両電極間に流れる電流はこのイオンの拡散特性 によって決まるが、このときの物質（イオン）伝 達係数が壁面せん断応力 $\tau$ の $1 / 3$ 乗に比例する。 この関傒は丁度、前述のホットフィルムプローブ の時と同様である。このことを利用して、液膜内 の局所壁面せん断応力を測定することが出来る。 
この手法は気液二相流研究において伝統的に今な おロシアの研究者によって多用されている（たと えば、[56]-[58])。Kashinsky ら[58]は作動流体 である蒸留水に $0.005 \mathrm{~N}$ のフェリシアン化/フェロ シアン化カリウムと $0.25 \mathrm{M}$ の水酸化ナトリウムを 溶解した電解液を用いている。電極は壁面に埋め 込まれ、流れ方向長さ $30 \mu$ 、横方向 $0.2 \mathrm{~mm}$ のマイ クロサイズである。これら一連の研究は気泡流で 行われたものであるが、この測定手法は液膜流に 対しても適用できるものである。

\section{9. おわりに}

気液二相流の液膜に関する測定法の一部を概観 した。古いものも含めて、代表的なもののみを述 べたが、調べるにつけ実に多くの方法が報告され ていることに改めて驚いた。編集委員会から頂い た紙数の倍以上のページ数になってしまったが、 使う立場で少し細かく書き過ぎたようである。液 膜流の測定手法は気泡流と比へ、非常に微妙な側 面があり、多くの手法にも拘わらず、非接触で瞬時 局所特性という、時空間領域での精緻な測定手法 は十分確立されているとは言えない。マイクロマ シン技術や高度なエレクトロニクス知識の応用、 流体力学の法則やさらにミクロな自然現象の法則 に従った革新的な測定技術の開発、コンピュータ による支援、等々今後の発展に待つところが多い。 また、幾つかの異なる原理、原則に基づく測定手法 の併用など、新しい展開の必要性もあろう。本稿が これから液膜測定をしようという研究者にとって 少しでも役立つところがあれば、幸いである。ま た、ここに取り上げることのできなかった優れた 測定手法の研究成果も多々あることをお断りする。

\section{参考文献}

[1] Hewitt, G.F., Measurement of Two-Phase Flow Parameters, Academic Press, New York (1978)

[2] Banerjee, S. and Lahey, R.T.Jr., Advances in Two-Phase Flow Instrumentation, in Advances in Nuclear Science and technology, Vol.13, edited by Lewins, J. and Becker, M., Plenum Publishing Co., New York (1980) 227-414.

[3] 傍島 真, 軽水炉安全性研究にかかわる二相流 計測器の最近の開発状況, 日本原子力学会 誌, Vol.23, No.11 (1981) 28-36.

[4] Delhaye, J.M. and Cognet, G., Measuring Techniques in Gas-Liquid Two-Phase Flow, Springer-Verlag (1984).
[5] 日本機会学会編、流体計測法, 日本機械学会, (1985) 158-164.

[6] 日本流体力学編, 流体計測ハンドブック (1998) 600-635.

[7] 芹澤昭示, 気液二相流の非接触計測法の現状に ついて, 日本原子力学会「1998 春の年会小講 演論文集(1998)II-1.

[8] Ishii, M. and Theofanous, T., Advanced Multiphase Flow Instrumentation and Measure- ment Techniques, Nuclear Engineering and Design, Vol.184, No.2-3 (1998) 161-460.

[9] Hagiwara, Y., A Study of Flow Characteristics and Heat Transfer of Annular and Dispersed Two- Component Two-Phase Flow, Dissertation, Kyoto University (1982).

[10] Ohba, K., Nakamura, K. and Naimi, F., A New Kind of Interfacial Wave on Liquid Film in Vertically Upward Air-Water Two-Phase Annular Flow, Proc. of the $2^{\text {nd }}$ Int. Conf. on Multiphase Flow '95-Kyoto (ICMF'95),

April 3-7, 1995, Kyoto (1995) IP1-27-33.

[11] Clark, W.W., Hills, J.H. and Azzopardi, B.J., Spatial Film Thickness Measurements in Falling Films in a Cocurrent Airflow Using a Novel Adaptation of the Light Absorption Technique, Two-Phase Flow Modelling and Experimentation 1999, edited by Celata, J.P. et al, Edizioni ETS, Pisa (1999) 1453-1440.

[12] Hewitt, G.F. and Hall-Taylor, N.S., Annular Two-Phase Flow, Pergamon Press, Oxford (1970).

[13] 芹澤昭示他、可視化による液膜流の動的挙動測 定法、混相流シンポジウム'94 (第 13 回) 講演論 文集 (1994) 95-98.

[14] Serizawa, A, Kamei, T., Nagane, K., Takahshi, O. and Kawara, Z., Non-Intrusive Measurement of Dynamic Behavior of a Liquid Film Flow, Proc. of the German-Japanese Symposium on Multiphase Flow, Aug.23-25, 1994, Karlsruhe, Supplement (1994) 63-73.

[15] Hewitt, G.F., Mrtin, C.J. and Wilkes, N.S., Experimental and Modelling Studies of Annular Flow in the region between Flow Reversal and the Pressure Drop Minimum, PCH PhysicoChemical Hydrodynamics, Vol.6, No.1/2 (1985) 69-86.

[16] Kawaji, M., Two-Phase Flow Measurents Using a Photochromic Dye Activation Technique, Nucl. Engng \& Design, Vol. 184 (1998) 379-392.

[17] Serizawa,A., Kamei, T., Kataoka, I., Takahashi O. and Kawara, Z., Visualization of Dynamic Behavior of a Liquid Film Flow Using a Fluorescence Dye Method, Two-Phase Flow Modelling and Experimentation 1995, Edizioni ETS, Vol.1 (1995) 197-201.

[18] Sekoguchi, K., Takeishi, M. and Ishimatsu, T., 
Interfacial Structure in Vertical Upward Annular Flow, Int. J. of PhysicoChemical Hydrodynamics, Vol.6, No.1/2 (1985) 239-255.

[19] Fukano, T., Measurement of Time Varying Thickness of Liquid Film Flowing with High Speed Gas Flow by a Constant Electric Current Method, Nucl. Engng \& Design, Vol.184 (1998) 363-377.

[20] Koskie,J.E., Mudawar, I. And Tiderman, W.G., Parallel-Wire Probes for Measurement of Thick Liquid Films, Int. J. Multi-phase Flow, Vol.15, No.4 (1989) 521-530.

[21] Kang, H.C. and Kim. M.H., The Develop- ment of a Flush-Wire Probe and Calibration Method for Measuring Liquid Film Thick- ness, Int. J. Multiphase Flow, Vol. , No. (1993)

[22] Serizawa, A., Tsuda, K. and Michiyoshi, I., Real-Time Measurement of Two-Phase Flow Turbulence Using a Dual-sensor Anemometry, in Measuring Techniques in Gas-Liquid Two-Phase Flows, edited by Delhaye,J.M. and Cognet, G., Springer-Verlag (1984).

[23] Coney, M.W.E., The Theory and Application of Conductance Probes for the Measurement of Liquid Film Thickness in Annular Gas- Liquid Flows, J. Phys. E: Scient. Instrum. Vol.6 (1973) 903-910.

[24］星出明彦、新留徳治、師岡慎一、石塚隆雄、 空気一水二相流管群内の液膜挙動に関する研 究、第 29 回日本伝熱シンポジウム講演論文集 (1992) 723-724.

[25] Swanson, R.W., Characteristics of the GasLiquid Interface in Two-Phase annular Flow, Ph.D. Thesis, Univ. of Delaware, USA (1966).

[26] Miya, M., Woodmansee, D.E. and Hanratty, T.J., A Model of Roll Waves in Gas-Liquid Flow, Chem. Engng Sci., Vol.26 (1971) 1915-1931.

[27] Brown, R.C., Andreussi, P. and Zanelli, S., TheUse of Wire Probes for Measurement of Liquid Film Thickness in Annular Gas-Liquid Flows, Can. J. Chem. Vol.56 (1978) 754-757.

[28] Daily, J.W. and Harleman, D.R.F., Fluid Dynamics, Addison-Wesley, Reading, Mass. USA (1966).

[29] 大場謙吉、高田浩哉、川上直之、液膜の局所膜 厚と界面波速度の同時測定のための光ファイ バー液膜センサ、日本混相流学会誌「混相流」、 3 巻 1 号 (1989) 50-66.

[30] 芹澤昭示、高橋 修、河原全作、米山智巳、岐 美 格、二相流衝突噴流による伝熱促進、第 26 回日本伝熱シンポジウム講演論文集 (1989) 866-868

[31] Serizawa, A., Takahashi, O., Kawara, Z. , Komeyama, T. and Michiyoshi, I., Heat Transfer Augmentation by Two-Phase Bubbly Flow Impinging Jet with Confined Wall, Heat Transfer
1990, Vol. (1994) 93-98.

[32] Serizawa,A., Nagane, K., Ebisu, T., Kamei, T. and Kawara, Z., Dynamic Measurement of liquid Film Thickness in Stratified Flow by Using Ultrasonic Echo Technique, Proc. of the $4^{\text {th }}$ Int. Topical Meeting on Nucl. Thermal- Hydraulics, Operations and Safety, April 6-8, 1994, Taipei, Taiwan (1994) 42-C-1-42-C-5.

[33] 芹澤昭示, 永根浩平、河原全作、蛭子 毅、 鳥越邦和、超音波による液膜厚さの測定、混相 流シンポジウム’94（第 13 回）講演論文集 (1994)289-292.

[34] 賞雅寛而、レーザーフォーカス変位計による液 膜界面波の測定、日本混相流学会誌「混相流」 Vol.12, No.1 (1999) 81-

[35] キーエンス社カタログ

[36] Takamasa,T., Kurabayashi, M. and Kobayashi, $\mathrm{K}$., Measurement of Interfacial Waves on a Film Flowing Down Wall Using Laser Focus Displacement Meters and an Image Process-ing Method, Paper presented at the $3^{\text {rd }}$ UK- Japan Mini-Seminar on Multiphase Flow and Nuclear Safety, February 10-11, 2000, Imperial College, London (2000).

[37] Matikainen, L., Iron, G.A., Morala, E. and Chang, J-S, Ultrasonic System for the Detection of Transient Liquid/Gas Interfaces Using the Pulse-Echo Technique, Rev. Sci. Instrum, Vol57, No.8 (1986) 1661-1665.

[38] Chang, J-S and Morala, E.C., Determination of Two-Phase Interfacial Areas by an Ultrasonic Technique, Nucl. Engng and Design, Vol.122 (1990) 143-156.

[39] 亀井敬史、芹澤昭示、超音波エコー法による模 擬燃料棒周りに形成される液膜流の瞬時二次 元液膜厚さ分布の測定、日本混相流学会誌「混 相流」、 12 巻 3 号 (1998) 249-254.

[40] Kamei, T. and Serizawa, A., Measurement of 2-Dimensional Local Instantaneous Liquid Film Thickness around Simulated Nuclear Fuel Rod by Ultrasonic Transmission Technique, Nucl. Engng and Design, Vol.184 (1998) 349-362.

[41] Kamei, T. and Serizawa, A., 2-Dimensional 3Local Instantaneous Liquid Film Thickness around Simulated Nuclear Fuel Rod Using Ultrasonic Transmission Technique, Proc. of the $3^{\text {rd }}$ Int. Conf. on Multiphase Flow (ICMF'98), Lyon, France, Paper No.316 (1998)

[42] 堀 慶一、超高速 X 線 CT スキャナによる気液 二相流ボイド分布変動計測、日本原子力学会 「1998 春の年会」予稿集（1998） II-6.

[43] Takeda, Y., Velocity Profile Measurement by Ultrasonic Doppler Method, Exp. Ther. Fluid Sci., Vol. 10 (1995) 444-453.

[44] Nakamura, H., Kondo, M. and Kukita, Y., Simultaneous Measurement of Liquid Velocity 
and Interface Profile of Horizontal Duct Wavy Flow by Ultrasonic Velocity Profile Meter, Nucl. Engng and Design, Vol.184 (1998) 339-348.

[45] Mishima, K., Hibiki, T. and Nishihara, H., Visualization and Measurement of Two-Phase Flow by Using Neutron Radiography, Proc. of the US-Japan Seminar on Two-Phase Flow Dynamics, Fukuoka, Japan (1996) 339-

[46] Mishima, K. and Hibiki, T., Development of High-Frame-Rate Neutron Radiography and Quantitative Measurement Method for Multiphase Fow Research, Nucl. Engng and Design, Vol.184 (1998) 183-201.

[47] Takenaka, N., Asano, H., Fujii, T. and Matsubayashi, M., Three-Dimensional Visualization of Void Fraction Distribution in Steady Two-Phase Flow by Thermal Neutron Radiography, Nucl. Engng and Design, Vol.184 (1998) 203-212.

[48] Takenaka, N.,Asano,H.,Fujii,T.,Yoshii,K., and Matsubayashi,M., Application of Thermal and Fast Neutron Radiography to Visualization of 3-D Void Fraction Distrubution of Gas-Liquid Two-PhaseFlow, Reprint, $\mathbf{1}^{\text {st }}$ European-Japanese Two-Phase Flow Group Meeting and $36^{\text {th }}$ European Two-Phase Flow Group Meeting, Portoroz, Slovenia, June 1-5, 1998(1998)

[49] 高橋 修、河原全作、芹澤昭示、河野益近、柿 木俊平、赤地久輝、陽子線ラジオグラフィ法 のよる蛇管細管ヒートパイプの沸騰および凝 縮現象の可視化、第 35 回日本伝熱シンポジウ 厶講演論文集、Vol. II (1998) 529-530.

[50] Cousins, L.B., Denton, W.H. and Hewitt, G.F.,
Liquid Mass Traansfer in Annular Two-Phase Flow, AERE-R4926 (1965).

[51] Leman, G.W., Agostini, M. and Andreussi, P., Tracer Analysis of Developing Two-Phase annular Flow, PCH PhysicoChemical Hydrodynamics, Vol.6, No.1/2 (1985) 223-237.

[52] Butterworth, D. and Pulling, D.J., Film Flow and Film Thickness Measurements for Horizontal Annular Air-Water Flow, AERE-R- 7576 (1973).

[53] Shiralkar, B.S., Two-Phase Flow and Heat Transfer in Multirod Geometries, A Study of the Liquid Film in Adiabatic Air-Water Flow with and without Obstacles, General Electric, USA. Report No. GEAP-10248 (1970)

[54] Hagiwara, Y., A Study of Flow Characteri- stics and Heat Transfer of Annular and Dispersed Two Component Two-Phase Flows, Dissertation, Kyoto University (1982).

[55] Mizushina, T., The Electr0-Chemical Method in Transport Phenomena, Advances in Heat Transfer, Vol.7 (1971) 87

[56] Kutateladze, S.S., Burdukov, A.P., Nakoryakov, V. Ye, and Kuzmi, V.Z., Application of an Electro-Chemical Method for Measurement of Shear Stress in Two-Phase Flow, Heat Transfer Soviet Research, Vol. (1969) 66-7.

[57] Nakoryakov, V.E., Kashinsky, O.N., Burdukov, A.P. and Odnoral, V.P., Local Characteristics of Upward Gas-Liquid Flows, Int. J. Multiphase Flow, Vol.7 (1981) 63-81.

[58] Kashinsky, O.N., Randin, V.V. and Chinak, A.V., Proc. of the $3^{\text {rd }}$ Int. Conf. on Multiphase Flow, ICMF'98, Lyon, France (1998) 